
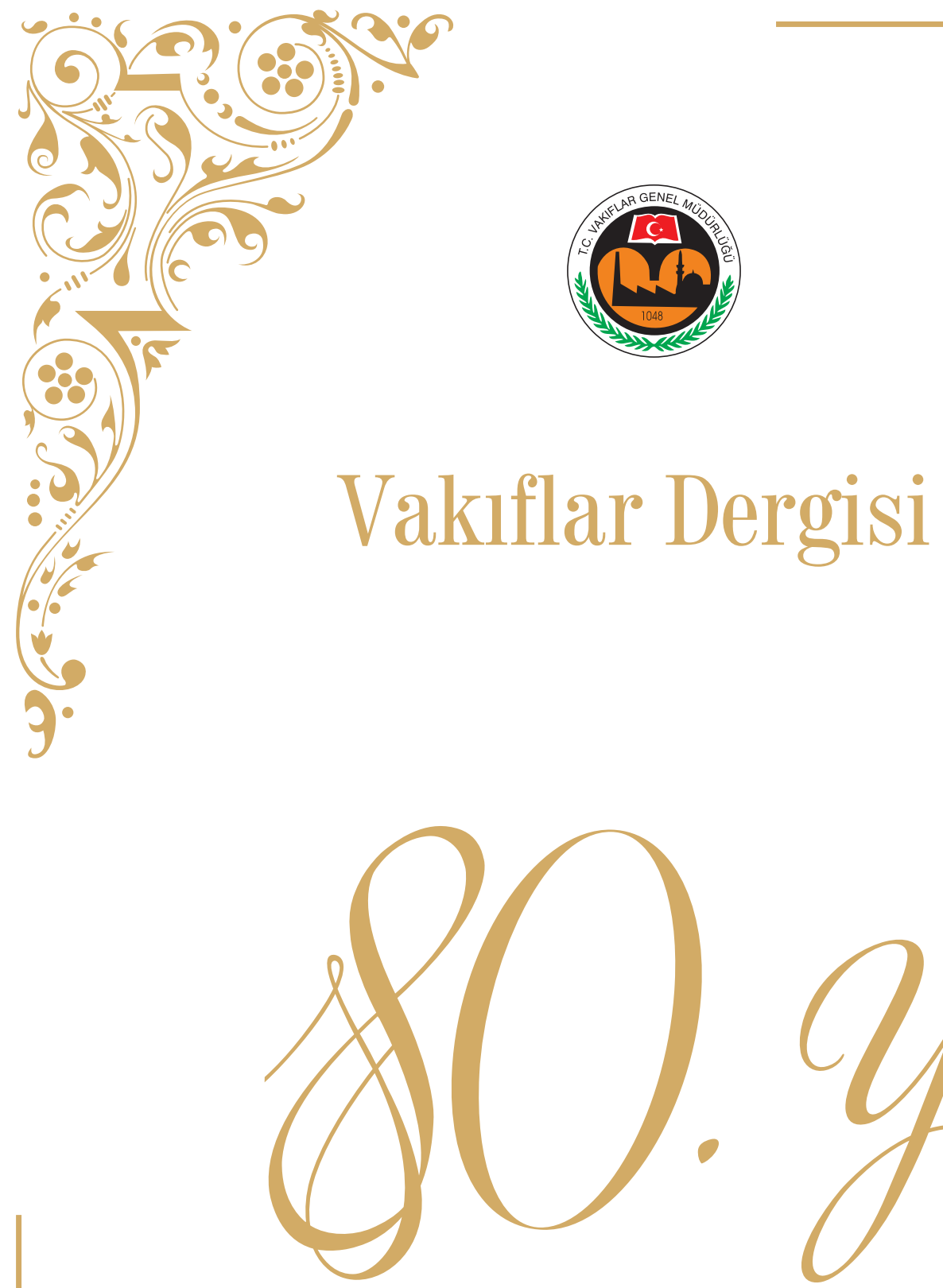

Ankara 2019

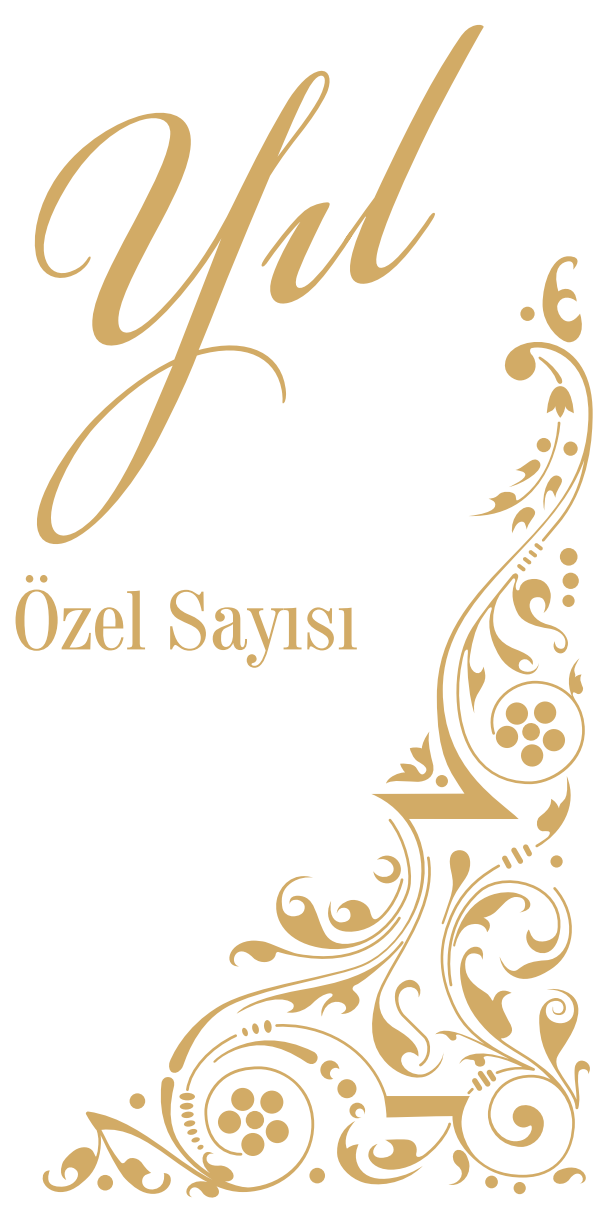




\section{VAKIFLAR DERGISI}

Yıl: 2019 - 80.Yıl Özel Sayısı - Hakemli Dergidir.

TÜBITAK ULAKBIM

Sosyal Bilimler Veri Tabanı (SBVTं) tarafindan taranmaktadır.

$$
\begin{gathered}
\text { Sertifika No: } 16651 \\
\text { ISSN: } 1011-7474 \\
\text { e-ISSN: } 2564-6796 \\
\text { Sahibi }
\end{gathered}
$$

Vakıflar Genel Müdürlüğü Adına

Dr. Adnan ERTEM

Yayın Koordinatörü

Rifat TÜRKER

Sorumlu Yazı Işleri Müdürü

Mevlüt ÇAM

Yayın Yönetmeni

Mehmet KURTOĞLU

Editörler

Hüseyin ÇINAR, Fatih MÜDERRISOĞLU

İngilizce Editörü

Miyase KOYUNCU KAYA

Tashih

Hasan DEMIRTAS

Dergi Sekreteryası

Hasan DEMIRTAŞ

Yayın Kurulu

Prof.Dr. Mehmet BULUT İstanbul Sabahattin Zaim Üniversitesi

Prof. Dr. Hüseyin CINAR Ankara Yıldırım Beyazıt Üniversitesi

Prof.Dr. Yılmaz KURT Ankara Üniversitesi (Emekli)

Prof.Dr. Mehmet ÖZ Hacettepe Üniversitesi

Prof.Dr. Ali YILMAZ Uşak Üniversitesi

Doç.Dr. Miyase KOYUNCU KAYA Ankara Yıldııım Beyazıt Üniversitesi

Dr. Öğr. Üyesi Fatih MÜDERRiSOĞLU Hacettepe Üniversitesi

Dr. Murat YILMAZ Ahmet Yesevi Üniversitesi

Yayın Danışma Kurulu

Prof. Dr. Mahmut AK İstanbul Üniversitesi

Prof. Dr. Enver ÇAKAR FIrat Üniversitesi

Prof.Dr. Abide DOĞAN Hacettepe Üniversitesi

Prof. Dr. Géza DAVID Macar Bilimler Akademisi

Prof. Dr. Abdullah EKiNCi Harran Üniversitesi

Prof. Dr. Özer ERGENÇ Bilkent Üniversitesi

Prof. Dr. Süreyya FAROQHI Bilgi Üniversitesi

Prof.Dr. Zekeriya KURŞUN Fatih Sultan Mehmet Vakıf Üniversitesi

Prof. Dr. Mahmut KAYA Ankara Üniversitesi (Emekli)

Prof.Dr. Yunus KOC Hacettepe Üniversitesi

Prof. Dr. Heath W. LOWRY Bahçeșehir Üniversitesi

Prof.Dr. ilber ORTAYLI MEF Üniversitesi

Prof. Dr. Hüsrev SUBAŞI Fatih Sultan Mehmet Vakıf Üniversitesi

Prof.Dr. Eugenia KERMELI ÜNAL Hacettepe Üniversitesi

Prof.Dr. Ayşııl TUUKEL YAVUZ Orta Doğu Teknik Üniversitesi (Emekli)

Prof.Dr. Bahaeddin YEDIYILDIZ Hacattepe Üniversitesi (Emekli)

Prof. Dr. Musa YILDIZ Ahmet Yesevi Üniversitesi

Dr. Öğr. Üyesi Vefa ÇOBANOĞLU İstanbul Üniversitesi

Dr. Rhoads MURPHEY Birmingham Üniversitesi (Emekli)

Evangeila BALTA Ulusal Yunan Araştırma Vakfi / Yunanistan

Mehmet Çetin Araştrmacı

Yayın ve Danışma Kurullarındaki isimler unvan ve soyadına göre alfabetik olarak sıralanmıştır.

Dergimize gönderilen yazılar, önce yayın kurulunca incelenir ve uygun bulunanlar, değerlendirilmek üzere alanında çalışması ile tanınmış iki hakeme gönderilir. Hakemlerin isimleri gizli tutulur ve raporlar beş yıl süreyle saklanır. Dergide çıkan yazılar kaynak gösterilerek iktibas edilebilir. Yayınlanan yazı, belge ve fotoğrafların her türlü hukuki mesuliyeti yazarına aittir.

\section{Yazışma Adresi:}

T.C.

Vakıflar Genel Müdürlüğü Kültür ve Tescil Daire Bașkanlığı

Vakıflar Dergisi Atatürk Bulvarı. No: 1006050 Ulus / ANKARA / TÜRKiYE

Tel: (0312) 5096000 - Faks: (0312) 3244722

e-posta: vakiflaryayin@yahoo.com - web: www.vgm.gov.tr 


\title{
IÇiNDEKILER / CONTENT
}

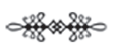

Vakıflar Hangi Statüde Bir İdarî Yapı İle Yönetilmelidir?

What should be the Statute and Administrative Structure of Waqfs?

Nazif Öztürk

İktisat Tarihi Açısından Vakıflar 73

Waqfs From The Perspective Of History Of Economics

Murat Çizakça

Nakid Para Vakfi İle İlgili Çivi-zâde'nin Ebussu'ûd’a Yazdığı Reddiye Risâlesi

Refutation of Chiwi-zadah against Abussu'ud Effendi on Cash Waqfs

Ahmet Akgündüz

Gelenekçi Osmanlı Islahat Düşüncesinde Temlikler ve Vakıflar

Waqfs and Temliks (Freehold Properties) in Traditional Ottoman Reform Thought

Mehmet Öz

Osmanlı Finansal Zihniyetinin Bir Göstergesi Olarak Para Vakıflarına Bir Bakış

A Look at the Cash Waqfs as an Indicator of Ottoman Financial Mentality

Mehmet Bulut - Cem Korkut

Osmanlı Su Yapılarında Vakıfların Rolü: Tesis, Onarım ve Hizmet Giderlerinin Finansmanı

Role of Waqfs in Ottoman Water Structures: Financing the Construction, Repair and Service Expenses

Said Öztürk

Muhasebe Kayıtları Işığında Mektep Vakıflarının Gelir Giderleri: 18. Yüzyıl Sonları Üsküdar Örneği ......

Income and Expenses of the School Waqfs in the Light of Accounting Records: Example of the Late 18th Century Üsküdar

Süleyman Kaya - Muhammed Emin Durmuş

Tuna Sahilinde On Altıncı Yüzyılda Kurulmuş Bir Osmanlı Yerleşimi: İsmail Geçidi Kasabası ..... 189

An Ottoman Town situated in the basin of Danube at the end of the sixteenth century: The town of İsmail Geçidi Mehmet Akif Erdoğru

Dedebalıların İzinde II: Dedebalı Zaviyesi ve Harmancık Kazası Dedebalı Karyesi

In Pursuit of Dedebali Community II: Dedebali Zawiyah and Dedebali Village of Harmancik District

Saim Savaş

Vakıf Medeniyeti.

Prof. Dr. Halil İnalcık

Prof. Dr. İlber Ortaylı İle Vakıf Medeniyeti Üzerine

Mahmut Bıyıkı

Semavi Eyice İle Bir Sohbet Bir Konferans

M. Sacit Pekak 
Bir Çınarın Ardından: Prof Dr. Hakkı Acun'un Yaşam Öyküsü ve Bilimsel Kişiliği.

M.Fatih Müderrisoğlu - Bülent İşler

Orhan Cezmi Tuncer: Her Vakıf Yapısında Tanrısal Güzelliği Gördüm .....

Mehmet Kurtoğlu

Hocası Prof. Dr. Rahmi Hüseyin Ünal'ın Kaleminden Sanat Tarihçi Yekta Demiralp

307

Rahmi Hüseyin Ünal

Türkiye'deki Bizans Sanatı Tarihinin Bir Çınarı: Hocam Prof. Dr. Yıldız Ötüken

311

Zeynep Mercangöz

Geçmişten Geleceğe Bir Vizyon Çizmek (Vakıflar Genel Müdürlüğü Yayıncılığı).

Publishing of General Directorate of Foundations; A Visionary Look From Past to Future

Mehmet Kurtoğlu

Vakıflar Dergisi 2013-2019 Yayın Dönemi (40-50. Sayılar) Değerlendirmesi ve Bibliyografyası

Waqfs Journal 2013-2019 Publication Period (40-50 issues) Evaluation and Bibliography

Hasan Demirtaş 


\section{Gelenekçi Osmanlı Islahat Düşüncesinde Temlikler ve Vakıflar Mehmet Öz*}

Öz

Osmanlı medeniyetinin temel kurumlarından biri vakıftır. Vakıflar sayesinde toplumun çeşitli ihtiyaçları karşılanmıştır. Bu çerçevede başta sultanlar ve hanedan mensupları olmak üzere yüksek rütbeli devlet adamları pek çok kamu hizmetinin karşılanması için hayır kuruluşları tesis etmişlerdir. Bunların bir kısmı ise padişahlar tarafından temlik edilen gelirlerin vakfedilmesi suretiyle meydana getirilmiş̧ir. XVI. Yüzyıl sonlarından başlayarak ve özellikle XVII. Yüzyılda Osmanlı devlet ve toplum düzeninde meydana gelen bir takım değişiklik ve "bozulma"ları ele alan, bunların düzeltilmesi için padişahlara tavsiyelerde bulunan islahat eseri yazarlarının üzerinde durduğu konulardan biri de bu tür temlikler ve vakıflardır. Herhangi bir hizmet olmadan yapılan temlikler ve vakıfların hazine gelirlerinin azalmasına ve dolayısıyla askerin zaafa düşmesine sebep olduğu ileri sürülmüştür. Bu makalede, söz konusu literatürde konunun ele alınışı̈ örneklerle tahlil edilmektedir.

Anahtar Kelimeler: 1slahat, vakıf, temlik, Osmanlılar, hazine.

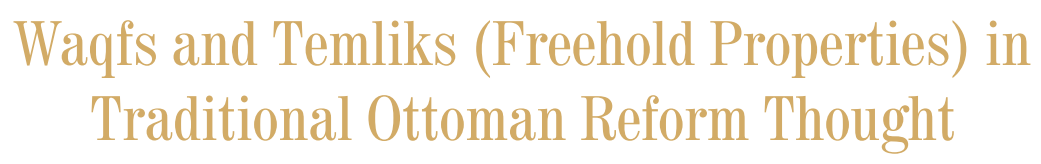

\section{Abstract}

Waqfs or pious endowments were one of the most important institutions of the Ottoman civilisation. They met various needs of the society as a whole. In this context the Sultans, members of the dynasty and prominent statesmen established pious endowments to serve the needs of the society. Some of these were founded through the income of freehold property (temlik) granted to statesmen by the Sultans. This was one of the issues dealt by the authors of reform reports (or 1slahat risalesi) who sought to analyse the reasons for the changes and so-called "decline" in the Ottoman state and society from the late 16th century and particularly throughout the 17 th century. They argued that those temliks granted and waqfs established without any benefit or service to the state caused the decrease in the income of the Treasury and hence the failure of the army. This article analyses, through examples, the way in which this issue is dealt with in the literature.

Key words: reform, waqf, freehold properties, Ottomans, treasury.

* Prof. Dr. Hacettepe Üniversitesi Edebiyat Fakültesi Tarih Bölümü. e-posta: mehoz@hacettepe.edu.tr; Orcid Id: 0000-0002-7806-7227 
Osmanlı siyasetnâme ve nasihatnâme literatürü ${ }^{1}$ çerçevesinde yazılan eserlerin üzerinde durdukları temel hususlardan biri iktisat zihniyeti ve politikalarıdır. Bu çerçevede değinilen konulardan biri de vakıflardır. Özellikle 16. yüzyılın ortalarından itibaren klasik Osmanlı sisteminde kanun-ı kadime aykırı görülen bir takım uygulamalar karşısında risaleler, nasihatnameler vb. yazılmıştır. Ancak belirtmek gerekir ki vakıf konusunda devletin uygulamalarına yöneltilen eleştiriler Fatih ve II. Bayezid devrine kadar uzanır.

Osmanlı iktisat ahlakı ve zihniyeti üzerindeki abidevi eserinde Ülgener'e göre (1981: 6569), dönemin iktisat anlayışı genel dünya görüşü çerçevesinde şekillenmiştir. Ona göre bu anlayış, "iktisat-dışı" değerlere bağlıdır ve ahlak anlayışının esasını maddî âleme karşı bir "mesafe şuuru" teşkil eder. Bu ise iktisadî faaliyetin mekânda cemaatleşme, zamanda ise gelecek kayg1sızlığı biçiminde tezahür eden sınırlanmasını beraberinde getirmekteydi. Netice itibariyle, K1nalızâde'nin (1248: 157) belirttiği gibi, kişinin kendisini ve yakınlarını geçindirmeye yetecek kadar emek ve çaba harcaması meşru idi: "Ziyade sây etmeyi müeddi-i noksan bulduk". ${ }^{2} \mathrm{Bu}$ sebeple, tarım ve zenaatkârlık maksada muvafık görülürken ticaret konusunda şüpheler izhar edilmiştir. Tüccarın sırf kâr için uzun ve zahmetli yolculuklara çıkması ruhî bir sapıtma olarak görülürdü (Ülgener, 1981: 78).

$\mathrm{Bu}$ genel anlayışa uygun olarak esnaf ve lonca ahlakı bir yandan, kanaatkârlık ve tevazua dayalı durgun bir nitelik taşımaktadır. Bu anlayış, sayı ve miktardan ziyade niteliği, mübadele değeri yerine kullanım değerini ölçü kabul ederken buna paralel biçimde "tavr-1 kadim”i, görenek (nakl olunana riayet) ve otoriteyi (usta-çırak ilişkisi) esas ittihaz ederdi. (Ülgener, 1981: 80-87)

Bu zihniyet ve ahlâk anlayışı iktisadî çözülme karşısında siyasî otoriteyi elinde bulunduranlar geleneksel telâkkilerle servet ve tüketimde kendi paylarını haklı çıkaracak argümanlar bulmakta zorlanmıyordu. Toplum düzeni için devlet adamlarına mal ve para lazımdı. Esasen adalet dairesi de bunu öngörür: "Mülk durmaz eğer olmazsa rical/Lazım amma ki ricale emvâl" ${ }^{3} \mathrm{Bu}$ yüzden de israf günah olmakla birlikte devletin haşmeti ve itibarı açısından devlet adamlarının debdebesi lüzumludur. Nitekim Naîma’ya göre (İpşirli, Naima I, 2007: 42), “...çün mülûk ve vüzerâ ve hükkâmın (...).. ziyb ü ziyneti lâzıme-i haşmet olup..." insanlar arasında derece ve rütbelerine göre, aşırılığa kaçmamak şartıyla farklılık olmasına dikkat edilmelidir. ${ }^{4}$ Devlet erkânından olmayanlara bu konuda ruhsat verilmemelidir. Yalnız "kuvvet-i mâliye ile müştehiyyat-1 nefsâniyelerini icrâ edenlerden iğmaz-1 ayn olunursa mansıb u câh izzetine rağbet kalmaz." (İpşirli, Naima I, 2007: 42) diyen Naîma, insanların sadece mallarının gücüyle, servetle nefislerinin isteklerini yerine getirmesi halinde, daha doğrusu buna göz yumulursa makam-mevki elde etmenin itibardan düşeceğini ifade etmektedir. İktisadî-malî güç elde etmenin yolunun devlet kapısından geçtiği anlayışını yansıtan bu görüş, iktisadî alana bakışı açısından da manidardır.

Osmanlı yönetim felsefesini yansitan siyasetname, nasihatname ve layiha türü eserlere ${ }^{5}$ baktığımızda iktisadî faaliyetler, maliye politikalarının genel yönetim açısından nereye oturtul-

1 Bu konuyu ve konu hakkındaki literatürü şurada değerlendirdik: Öz (2017). Osmanlı siyasi düşüncesi hakkında kapsamlı yeni bir çalışma için bk. Sariyannis (2019).

2 Buraya işaret eden: Ülgener (1981: 72).

3 Nabî'den nakleden Ülgener (1981: 104).

4 Buraya Ülgener dikkati çekiyor, bk. Ülgener (1981: 104).

5 Bu literatür hakkında çeşitli değerlendirmeler vardır. Genel olarak bk. Öz (2005); Yılmaz, C. (2003): 299338; Y1lmaz, H. (2003: 231-298). 
duğunu anlayabiliriz. Bu yazıda özellikle 16-17. yüzyıllar nasihat literatürünün bazı örneklerinden hareketle konuyu incelemeye çalışacağız. Bu yönetim anlayışının temel düsturu, adalet kavramı olup daire-i adliye olarak ifade edilir. Kınalızâde'nin Ahlâk-l Alầ̂'sinde bunu şu şekilde buluyoruz: "Adldir mûcib-i salah-1 cihan; cihan bir bağdır dıvarı devlet; devletin nâzımı şeriattır; şeriata hâris olamaz illâ melik; melik zapteylemez illâ leşker; leşkeri cem’ edemez illâ mal; malı cem' eyleyen reâyâdır; reâyâyı kul eder padişah-1 âleme adl.” (Kınalızade, 1248: 49).

Bu kavramda özetle şu ifade edilmektedir: Adalet dünyanın kurtuluşunu sağlar; dünya, duvarı devlet olan bir bağdır; devleti düzenleyen şeriattır; hükümdar olmadan şeriat korunamaz; askersiz hükümdar duruma hâkim olamaz; mal olmadan hükümdar asker toplayamaz; malı toplayacak olan halktır; halkı padişaha kul eden ise adalettir. Daha özet versiyonlarından hareketle adalet dairesinin birbirine bağlı temel kavramlarını şöyle ifade etmek gerekir: Mülk[devlet, egemenlik, hükümdarlık]-Asker-Hazine-Reâyâ-Adalet. Bunlar birbirine bağlıdır ama esas itibariyle ülke düzeninin, yönetimin (mülk) ayakta durmasının temeli adalettir anlayışı hakimdir. Bu düşünceyi ifade eden vecizelerden biri de "Küfr ile dünya durur, zulm ile durmaz" (Aksüt, 1939: 42; Kurt, 1994: 62) şeklindedir. Bir başka ifadeyle, eğer bir devleti idare edenler Müslüman olmamakla birlikte adalete riayet ediyorsa o ülkenin düzeni ayakta durur; buna mukabil yöneticileri Müslüman olan bir ülkede adalet yerine zulüm hâkimse o ülkenin karışıklığa duçar olması mukadderdir. Nitekim bu vecize 14. yüzyılda Şeyhoğlu Mustafa'da da benzer bir şekilde ifade edilir: "padişahlık baki olur küfr ile-adl olıcak ve illa baki olmaz iman ile-zulm olıcak" (Yavuz, 1991:106-107). Hülasa, üretimin sağlıklı bir zeminde yapılabilmesi ancak, Tanrının hükümdarlara emaneti olan (vedâyi-i Hâlik-i Kibriyâ) vergi veren halka adalet ve insaf üzere davranılması ile mümkündür. Halk huzur ve refah içinde olduğu takdirde üretim ve dolayısıyla vergiler açısından bir sıkıntı olmaz. Bu ise devleti/mülkü/hükümdarlığı ayakta tutacak olan askerî gücün temini açısından son derecede önemlidir. Hükümdar da adaletle yönettiği sürece ülkenin bütün nizamı dengede olur.

$\mathrm{Bu}$ genel çerçevede, yönetimde askerî ve malî tedbirlerin birbirine bağlı ele alınması en belirgin özeliklerdendir. Kanunî’nin veziriazamı Lütfi Paşa, vezirlere öğütler niteliğindeki Âsaf-nâme adlı eserinin hazine tedbirleri ile ilgili kısmına şöyle başlar: "Evvelâ tedbîr-i hazîne umûr-1 mühimmedendür, Saltanat hazine ile olur ve hazine tedbîr ile olur, zulm ile olmaz." (Kütükoğlu, 1991: 49-99). Bunun için dikkat edilmesi gereken en önemli gösterge gelirin giderden fazla olmasıdır (îrâd masrafa gâlib gerekdür). Bu çerçevede hem askerî hem de malî açıdan ulufeli kul taifesini çoğaltmaktan sakınmak gerekir. Kısacası onun fikirleri malî disipline sıkıca uyulması olarak özetlenebilir. Mehmet Genç, Osmanlı iktisat düşüncesinin temel mantığını ve dayandığı teorik ilkeleri irdelediği çalışmasında bu prensibi fiskalizm olarak adlandırır (Genç, 2000: 43-76).

Kınalızâde Ali, toplum düzeni açısından tedbirin gerekliliğini ifade eder: “(bu) siyaset-i uzmâdur ki bununla içtimâ mümkün ve fesad mündefi olur.” Bunu gerçekleştirmek için üç şeye ihtiyaç olduğunu belirten yazara göre bunlardan biri de "dinar-1 nâfi" dir. ${ }^{6}$ Dinar-1 nâfi' faydalı para, kazanç demektir. İnsanların bir araya gelmeleri, karşılıklı alışverişi gerektirir. Bu ilişkiler ise adalet üzere olmalıdır. Bu noktada paranın düzen açısından rolü de vurgulanmış olmaktadır (Daire-i adalet formülündeki gibi). Eserlerinden yararlandığı Nasıreddin-i Tusî ve Celaleddin-i

6 Diğer ikisi Nâmûs-ı Şâri' ( şeriat-1 ilahî) ve Hâkim-i Mâni' (İmam, halife, hükümdar)dir. 
Devvanî gibi Kınalıâde de parayı âdil-i sâmit (adaleti sesszice sağlayan güç) olarak görür (Unan, 2004: 101).

Hazine meselesi 1slahata müteallik eserlerde de temel konulardan biridir. Mesela, Kitâb-l Müstetâb'da, III. Murad'ın tahta geçmesinden sonra devletteki bozulma açısından en kritik hususlardan birisi olarak ehliyetsiz devlet yöneticilerinin kanun-ı kadime aykırı faaliyetlerinin yol açtığı gelir-gider dengesizliği meselesi ele alınır. Bu yöneticilerin adalet, yerine getirmede kusurlarının olduğu ve yanlış uygulamalar yaptıklarını ileri süren yazar, pek çok ihmaller yüzünden ülkedeki köy ve ekinliklerin harap olduğunu, köylülerin yerlerini terk ettiklerini ve netice olarak hazinenin gelirinin giderlere yetmez hâle geldiğini ifade eder:

"Fe-emmâ müşârûn-ileyh merhum Sultan Murâd Hân-Tâbe serâhuhazretlerinin zamân-1 sa'âdetlerinden berû olan hükkâm ve vükelâ-i devletin adâletliklerinde kusûr ve işlerinde sû-i tedbir ve Devlet-i Aliyye umûrunda nice ve nice ihmâlleri olub dâ'imâ kanûn-1 kadîme muhâlif mesleke sâlik oldukları eclden Memâlik-i mahrûsada olan kurâ ve mezâri’ harâba yüz tutub re'âyâ ve berâyâ perâkende olub ve Hazîne-i âmirenin irâdı masrafa kifâyet etmez olub ..." (Yücel, 1988: 2).

$\mathrm{Bu}$ durum sonraki eserlerde de aynı anlayışla ele alınmıştır. Mesela Koçi Bey zeamet ve timarın önceki haline konulması ve kul taifesinin sayısının azaltılması ile düzenin sağlanacağı kanaatindedir (Aksüt, 1939: 51; Kurt 74). Gerçekten de Koçi Bey’in malî konulara bakış1, hazinenin dengesi çerçevesindedir. Reâyânın durumunu ele aldığı kısımda ulufeli kul taifesinin sayısının artmasının masrafı arttırdığını, masraf arttıkça halk üzerine yüklenen verginin de arttığını, bunun ise reâyânın zulme uğramasına ve neticede ülkenin harap olmasına sebebiyet verdiğini vurgular. ${ }^{7} \mathrm{Bu}$ klasik daire-i adliye kavramı çerçevesinde yapılmış bir yorumdur. Nitekim Koçi Bey de eserinde bu kavramı yer yer zikreder. ${ }^{8}$ Bundan sonra vergilerin nasıl arttığ 1 açıklanır. Savaşlarda kaybedilen topraklardaki havass-1 hümayun gelirlerine ek olarak bazı hasların "hilâf-1 şer"” yani şeriata aykırı olarak temlik, vakıf ve paşmaklık olduğu üzerinde durulur.

\section{Hazine Gelirlerinin Haksız Aktarımı: Temlikler ve Vakıflar}

Temlîk "mülk olarak vermek" demektir. Terim anlamı ise "hükümdarın mîrî araziden veya şahıslardan devlete intikal eden arazi ve binalardan bazı yerleri devlete hizmet etmiş kimselere mülk şeklinde tahsis etmesi”dir (İpşirli, 2011: 430-431). Osmanlı mirî arazi rejimi çerçevesinde bilhassa ileri gelen devlet adamları başta olmak üzere birtakım kişilere mirî araziden toprak temlik edilmesi yaygın bir uygulama idi ve devletin bir takım politikalarında uygulanan bir usuldü. Barkan'ın belirttiği üzere, bazen "Mihal Bey oğulları mülklerinde olduğu gibi, fütühata iştirak ve hizmet etmiş olmanın temin ettiği bir hak ve mükâfat olarak” verilirdi. Ancak bu tür fetih hakkından dolayı yapılan temlik örnekleri azdır; buna mukabil keyfî temlikler söz konusudur. Mesela, Sultan İbrahim devrinin meşhur Cinci Hoca'sına Bolu Sancağında toplam geliri 66.925 akçe olarak yazılan köy, mezraa ve sair vergi kaynaklarının geliri ebediyen mülk olarak verilmiştir (Barkan 1980:262-263).

7 "Hala kul taifesi ziyade olup kul ziyade oldukça masraf ziyade olup, masraf ziyade oldukça teklif ziyade olup, teklif ziyade oldukça reayaya teaddi ziyade olup âlem harab olmuştur” (Aksüt, 1939: 47, Kurt 1994: $60)$.

8 "Velhasıl saltanat-1 aliyyenin şevket ve kudreti askerile ve asakirin bekası hazine iledir, ve hazinenin tahsili reaya iledir, ve reayanın bekası adl ü dad iledür.” (Aksüt, 1939: 50; Kurt 1994: 65). 
Osmanlıların bir uç beyliğinden cihan devletine yükselme sürecinde çeşitli kurumların yanında devletin, Barkan'ın deyimiyle, "bir iskân ve kolonizasyon metodu olarak vakıflar ve temlikler”i kullandığı öteden beri vurgulanan bir husustur. Mirî arazinin ve gelirlerinin bu şekilde temlik edilmesi ve bilahare bunların vakfedilmesi genellikle müspet yönleriyle tezahür etmiştir. ${ }^{9} \mathrm{Ne}$ var ki ilerleyen dönemlerde bu durum değişecektir.

Temlik meselesi Osmanlı Devletinde müşahede ettikleri "bozulma” (tagayyür ve ihtilâl) ve yapılması gerekli "1slahat” üzerinde duran eserlerde değinilen konulardan biridir. Mirî toprakların temlik edilerek vezirler ve ekâbirin kurduğu vakıflar için kullanılması hususunda bazı risale yazarları sert eleştiriler yapmıştır. Bu çerçevede temlik ve vakıf konusunu vurgulayan eserlerden biri de III. Murad'a sunulduğu anlaş1lan Hırzü'l-mülûk'tür. Yazar, timar sistemi içindeki toprakların vakıf ve mülk haline getirilmesinin orduyu zaafa uğrattığını ileri sürer:

"Ve saltanatun bekası adalet ve yarar asker iledir ve askerin tâbi olması istihkaklarına göre dirlik verilmekledir. Ve bu vech ile riayet olunmağa vafir memleket ve müstevfi hazine gerekdir ki bazısına ulûfe ve bazısına zeamet ve timar ve sayir âli mansıblar virile. Bu takdirce memalik-i mahrusede vaki olan kasabalar ve karyelerin ekseri havass-1 hümayun ve zeamet ve timarlar olmak lâzım iken şimdiki hâlde ekseri vakıf ve mülk olup zeamet ve kılıç timarlar cüz'î kalmıştır. Hele selâtîn-i ‘izam evkafına ne söz ki kuvvet-i kahireleriyle feth ettikleri memleketlerden imaret ve camilerine vakfetmişlerdir. Hak subhanehu ve teâlâ kabul itmiş olup cümlesin rahmeti deryasına müstağrak itmiş ola. Amma insaf mıdır ki sayir in'am ve ihsandan maada yalnız bir vezire kırk-elli pare karyeler temlik oluna? Vezaret gibi âli mansıb ile riayet olundukları kifayet itmez mi? Hususa vezir-i azam olana karye temlik olunmağa ne ihtiyaç?” (Yücel, 1988: 176-177) ${ }^{10}$

Burada daire-i adliye kavramı çerçevesinde saltanat ve devletin bekasının güçlü bir ordu ile mümkün olduğundan hareket eden yazar, güçlü orduyu muhafaza etmenin de ülkenin geniş topraklara ve yeterli bir hazineye sahip olmasının şart olduğunu vurgular. Söylenen kabaca şudur: $\mathrm{Bu}$ hazine ve topraklar sayesinde askerin kimisine maaş (ulufe) kimisine de dirlikler (timar, zeamet ve has) verilmelidir. Halbuki artık Osmanlı ülkesindeki köy ve kasabaların çoğu has, zeamet veya timar olması gerekirken vakıf ve mülk haline gelmiştir. Büyük sultanların vakıflarına söz denilemez, kendileri fethettikleri yerlerden cami ve imaretlerine vakfettiler. $\mathrm{Ne}$ var ki, vezirlere, veziriazama böyle çok sayıda köyün temlik edilmesine hiç gerek yoktur. Maalesef veziriazamlar başkalarının köy, mezraa, değirmen, çiftlik, hamam vs.ni bir yolunu bularak almıştır. Bu konuda en çarpıcı örnek, Kanuni’nin yüz parça kadar köy, mezraa, kasaba, iskele vb.yi temlik ettiği Sokullu Mehmed Paşa'dır. ${ }^{11}$ Bu kadar çok köy ve ekinliğin mülk olarak verilmesinin sebebi ise şöyle açıklanır:

9 Bu konuda geniş bir literatür var. Bu çalışmaların öncüsü olarak Ö. L. Barkan'ın çalışmaları bilhassa önemlidir (Barkan 1942).

10 Alıntıyı aktarırken transliterasyonunda sadeleştirmeye gittik. Uzunlukları göstermedik, bugünkü imlaya göre bazı değişiklikler yaptık ("idüp” yerine edip, "yazdurur” yerine "yazdırır”, "sınur” yerine "sınır”, "zi'amet" yerine "zeamet" vb.)

11 “... Veziriazam Mehemmed Paşa [Sokullu] Hazretleri kullarına merhum ve mağfurun leh Sultan Süleyman Han (...) Hazretleri ile (...) merhum Padişah [II. Selim] Hazretleri yüz pare mikdarı karyeler ve mezraalar ve müstakil kasabalar ve iskeleler ve nice mahsul verir yerler temlik buyurmuşlardır." (Yücel, 1988: 177) 
“... vezir-i azam olduktan sonra adalet edip felekte bir nâm komağa mukayyed olmayıp hemen firsat el vermişken kendimize vâfir karyeler temlik ettirelim; kimini vakfedip ve kimi evladımıza kalsın diye bu sevdayile vilâyeti yazdırmağa mübaşeret edip gönderdikleri kâtiplere muhkem tenbih ideler ki: "Kendimize bazı karyeler temlik ettirrmek isteriz; gerektir ki yazdığınız yerlerde etrafı vâsi mahsullü karyeleri, kimini bin beş yüz akçaya ve kimini bin akçaya ve bazı a'lâ mezraaları üçer-dörder yüz akçaya yazasın." diye 1smarlamağın onlar dahi tek hidmet yanaşdıralım diye bir kurı iltifata dinin ve imanın satıp on beş ve yirmi bin akçaya ve dahi ziyadeye mütehammil olan karyeleri defter-i cedid'e bin ve bin beş yüz akçaya ve dahi aşağı yazıp..."

Kısaca izah etmek gerekirse, tahrir sırasında köylerin gelirleri olduğundan çok düşük gösterilir, böylece bunların temlik edilmesinde bir beis görülmez. Köyler ve mezraalar bütün vergileri ile serbestiyet üzere temlik edilir. Köylerin sınırlarının tespitinde de oradaki kadı veya müderris de en verimli zeamet ve timar topraklarını içine alacak şekilde sınır tayin eder. Dirlik sahipleri de korkularından itiraz edemezler. ${ }^{12}$

$\mathrm{Bu}$ temlik edilen yerlerin her türlü vergiden muaf tutulması yüzünden başka yerlerin reayası buraya gelir ve kendi yerlerinde vergi geliri düşerken buraların gerçek geliri defterdekinden kat kat fazla hale gelir. Böylece beytülmal israf edilir. Bu tür temliklere karşı olan yazar, cami ve imaret inşası için vezirlere en fazla bir iki köy temlik edilebileceğini ekler. Sonuçta, “... memleket ve vilayetler feth olunmaktan maksud tevsi-i memalik ve teksîr-i hazayindir; yohsa vüzeraya ve gayra temlik için değildir." (Yücel, 1988: 178); yani ülkeleri fethetmenin sebebi, devletin topraklarını genişletip hazineyi çoğaltmaktır, vezirlere ve başkalarına mülk vermek değildir. Eğer bir yere cami veya diğer hayrat gerekirse bunu daha önce hayratı olmayan birisi bina etmeli; talip yoksa bizzat padişah işe el atmalıdır. Vezirlerin ve diğer kulların salt reayadan mal celbederek cami ve imaret yapması doğru değildir. Bu, "öksüz oğlanın kaftanın arkasından alup dul avrata geyürmek gibidir." (Yücel, 1988: 179)

Burada, özellikle kamu hizmetlerinin yerine getirilmesi bağlamında beytülmala ait gelirlerin bir takım kişilere tahsis edilmesi, onların da kendi evladının menfaatini de garanti altına alarak vakıflar tesis etmesi yerine, bizzat padişahın bu gibi hayratı yapması önerilmektedir.

Osmanlı ıslahat risâlelerinin en tanınmışı olan Koçi Bey Risalesi'nde şeriata aykııı temlik ve vakıflar konusu üzerinde etraflıca durulur. Koçi Bey’i şu özlü ifadesi, "kanun-ı kadimin ihlali ve düzenin bozulması" hususundaki temel felsefesini yansitan bir örnektir :

“Hilaf-1 şer'-i şerif bazı temlikler ve vakıflar vardır. Egerçi sureta hayır görünür, amma inde’t-tahkik izaat-1 Beytülmaldir. Zira memalik-i İslamiy-

12 “... defterin südde-i saadete götürdüklerinde ol asıl karyeleri telhis edip pâye-i serire gönderdikte anlar dahi görürlerdi ki yazıları cüz'i birkaç karye ve mezraadır, çok nesne değil diye temlik buyururlardı. Badehu her birine yazdırdıkları mülk-nâmede falan karye ve mezrayı cemi’ hududu ve tevabi’ ve levahıkı ile ve öşr-i gallâtı ve haracı ve ispençesi ve mâl-1 gâyibi ve mâl-1 mefkudı ve beytü'l-mâlı ve yavaşı ve kaçgunı ve cürm ve cinayeti ve resm-i arusanesi, kul ve cariye müjdeganesi ve sayir bâd-1 havâsı ve re'âyâsı ve evlâd-1 re'âyâs1 ve evlâd-1 evlâd-1 re'âyâs1 ve haymanası ve evlâd-1 haymanası ve evlâd-1 evlâd-1 haymanası ile bi'l-cümle kâffe-i hukuk-1 şer'iyye ve 'amme-i rüsum-1 örfiyyesiyle mimma zükire ev lem yüzkerü min külli'l vücuh serbest ve mefruzü'l-kalem ve maktu'u'l-kadem temlik eyledim diye yazdırırlar.” (Yücel, 1988: 177-178) 
yede olan kura ve mezari mahsulatı ki Beytülmale sarf olunur, guzat ve erbab-1 mukatele hakkıdır. Şer'an masraf-ı muayyeni vardır”. (Aksüt, 1939: 55; Kurt, 1994: 72).

Şeriata aykırı vakıfların görünüşte hayır işi, gerçekte ise Beytülmalin kaybı, zarara uğratılması olduğunu ileri süren Koçi Bey, Beytülmale ait olan köy ve mezraaların gazilerin ve savaşçıların hakkı olduğunu belirtir. Bu türden vakıfların sahih olmayacağını söyleyen Koçi Bey, Gazi Evrenos Bey, Turahan Bey, Mihaloğulları gibi Allah rızası için gaza edip ülkeler fetheden beylere hizmetleri mukabelesinde yapılan temliklerle meydana getirilen hayır eserlerinin vakıflarını din ulemasının caiz gördüğünü de ekler. Bir başka yerde, Kanunî Sultan Süleyman devrindeki bozulmayı anlatırken o devirde alemin düzeninin karışmasına yol açan "ihtilâl-i âleme bâis olan maddeler" hususlardan birinin kızı Mihrimah ile damadı Rüstem Paşa'ya önceden fethedilmiş topraklardan temlikler yapması, onların da bunları vakfetmesi olarak belirtilir. $\mathrm{Bu}$ gibi sultanların vakıfları daha önceden öldükleri zaman mirî haslara alınırken, sonra gelenlerin de vakfetmesiyle şeriata aykırı biçimde hazine malının ziyan olduğunu ileri süren (Aksüt, 1939:63, Kurt 1994: 85-86) Koçi Bey’e göre bu tür hizmetlere mukabil yapılan temlikler sayesinde meydana getirilen vakıflar sahihtir, diğerleri değildir. Bunun konumuz bakımından önemi, devlet hazinesinin bu gibi temlikler yüzünden uğradığı zararla ilgilidir. Nitekim Koçi Bey de Beytülmal hakkı olan bu tür yerlere soruşturulup geri alınsa binlerce kılıç timarı ihdas edilebileceğini, hazinenin dolacağını ve pek çok yararın elde edileceğini belirtir. Tabii bu yüzden vakıflarla ayakta duran cami ve mescitlerin de ihmale uğraması doğru değildir. Neticede Koçi Bey, haksız yere yapılan ve meşru olmayan (nâ-meşru) temliklerin mirîye geçmesi sayesinde eskiden var olanlarla birlikte yüz binden ziyade zeamet ve timar sahibinin ortaya çıkacağı kanaatindedir:

"Bir âdem din ü devlete lâyık hıdmet görmeye ve memleket değil belki de bir karye fethetmeye, mücerred mukarreb-i padişahî olmağla nice yüz y1l mukaddem feth olunmuş memleketten beytülmâl-1 sarf nice kurâ ve mezari' birer tarik ile kendülere ve evlâdlarına temlîk etdirmişlerdir. Badehu diledikleri yeri vakf edüb bazılar dahi vakf nâmına evlâdlarına akâr etmişlerdir. Ol makule vakf nice sahih olur? Ve anı besmele ile nice tenâvül câiz olur? (...) Din ü devlete lâyık olan budur ki, iki yüz yıldan beri temlîk ve evkâf olan karyeler hakk u adl üzere yoklanub meşru olan temlîk ve vakıf karyeleri hâli üzere ibkâ buyurulur ise nâ-meşrû olub hakk-1 beytü'l-mâl olanlar ulûfeli kul tâ'ifesine tevzi' ve taksîm olub nice bin k1liç ihdâsuına sa'y-i hümâyûn buyurula. (...) kadimî olan k1liçlarla cem’ân yüz binden ziyâde zu'amâ ve erbâb-1 timâr zuhura gelür." (Aksüt, 1939: 56; Kurt, 1994: 73-74).

Görüldüğ̈̈ gibi burada mesele, devletin askerî gücünü ihya çerçevesinde ele alınmaktadır. Şeriata aykırı temlikler hazinenin zarara uğramasına, bu ise askerî gücün zaafa uğramasına sebep olmuştur. Yapılacak şey süreci tersine çevirerek devletin malî ve askerî gücünü geri getirmektir.

Rhoads Murphey tarafından yayımlanan ve muhtemelen Koçi Beğ tarafından kaleme alınan Veliyüddin telhislerinde genelde, yapılması gereken ıslahattan söz edilmektedir. Şikâyet konularından birisi de şeriata aykırı olarak ihdas edilmiş vakıflar ile temliklerdir. Bunların ortaya 
çıkarılıp timar ve zeamet olarak dağıtılmasıyla pek çok faydalar sağlanabilirdi (Murphey, 1979: 563-564). "Hilâf-1 şer'-i şerif temlik ve evkaflar erbab ü ashabına tevzi olunması beyanındadır" başlıklı telhisde, icmal defterinde kılıç kayd olunan timar ve zeametlerin bazısının arpalık veya paşmaklık olduğu, bir kısmının da padişah haslarına katıldığı vb. hususları eleştiren yazar, Hüseyin Paşa'nın timar meselesini hak ve adalet üzere yoluna koymaya başladığına işaret eder. Daha sonra yazarımız temlik ve vakıflar konusunda özetle şunlar belirtiyor:

“ ... feth olunmuş memalikten bazı kimesneler selâtîn-i seleften birer tarîk ile nice kurâ ve mezari' alıp vakf etmişlerdir. Ol makule temlikler hilâf-1 şer'-i şeriftir, caiz değildir. Hilâf-1 şer'-i şerif olan vakıftan sevap ihtimali yoktur. Vebal-i azimdir. Meselâ, Sultan Süleyman Han (...) kerime-i mükerremesi Mihrimah Sultan merhumeye ve Rüstem Paşa'ya hadden ziyade temlikler hibe eyleyip vakf eylemişlerdir." (Murphey, 1979: 563).

$\mathrm{Bu}$ ve benzeri vakıfların gelirinin dirlik olarak tahsis edilmesi durumunda meydana gelecek askerî güç sayesinde Safevîlerle mücadelede üstünlük elde edilebilirdi. Yazar, Padişahtan kırk elli erdem sahibini çağırıp şunu sormasını talep eder: Fethedilen ülkelerden din ve devlete layık hizmette bulunmayanlara eski sultanların hibe ve temlik edip onların da kimisinin camilerine kimisinin de medreselerine vakfetmeleri şer'an caiz midir? Yazara göre;

"Caiz olmayan temlik haram-1 sırfdır. Iyazenbillah bismillah denilmez. Bu takdirce iki yüz yıldan beru hilâf-1 şer'i- şerif ihdâs olunan evkâf eğer selâtîn ve eğer vüzerâ evkâfıdır, dikkat üzere görilüb zevâidi tarh olunub nukûddan mürtezikâ vazifeleri edâ olunub â'şarı ve re'âyâsı timar virse ne mikdar asker peydâ olurdu." (Murphey, 1979: 564)

Bu hususta diğer 1slahatçılarla aynı çizgiyi paylaşan ve aşağı yukarı Koçi Bey’le benzer cümleler kullanan yazarın timar sisteminin ihyası için yapılması gerekli idarî ıslahatı da etraflıca tasarladığı anlaşılıyor. Yazar açısından önemli olan nokta, hak etmeyenlere yapılan temlikler ve bunların vakfedilmesi yüzünden devletin askerî gücünün zaafa uğramış olmasıdır.

IV. Murad'ın bir musahibi tarafından yazıldığı anlaşılan (Murphey, 1985: VII-VIII) Kanûnnâme-i Sultanî li Aziz Efendi adlı eserde veziriazamlara müteallik olan kanunlar anlatılırken bu meseleye de değinilir:

"Ve selâtîn-i selef feth-i hâkânîleri ile müşerref buyurdukları memalik[de] ba'zı kurâyı dîn [u] devlete hizmeti sebkat etmeyen nice nâ-müstahıkka hilâf-1 şer'-i şerîf hibe ve temlîk olunmağla anlar dahi mescid ve medrese binâ edip vakf etmişlerdir ve zevâ'idi evlâdlarına ta'yîn etmişlerdir. Ol makule hilâf-1 şer' u kânûn olan vakıflarda sevâb ihtimâli yoktur. Bu takdirce nâ-müstahıkka ber-vech-i temlîk verilen karyeleri yarar kılıç dilâverlere tevzi' ve tevcih buyurulmak evlâ ve enfâ'dır. Ammâ mücerred ol mesâcid ve medâris ve sâ'ir hayrât mu'attal kalmamak için her kime sadaka olur ise mürtezikasını irzâ eyleyip mâ'âdası mutasarrıf ola. İnşa'llahu te'âlâ hilâf-1 şer'-i şerîf ve mugayir-i kanûn-1 münîf olan temlikler bu minvâl üzere tevcih ve sadaka olunan dilâverler ile bir kavî düşmana cevâb verecek 'azîm ‘asker hâs1l olur.” (Murphey, 1985: 29). 
Görüldüğü gibi, Koçi Bey ve Veliyüddin telhislerinde geçen argüman ve ifadelere benzer ifadeler kullanan Aziz Efendi de kanûn ve şeriata aykııı temliklerden şikâyetçidir. Hak etmeyen kişilere temlik edilen köylerin, bu kişilerin inşa ettirdiği câmi, medrese vb.ye vakfedildiğini, masraflardan artan gelirin ise evlâd-1 vâkıfa gelir tahsis edildiğini belirten yazar, böyle haksız bir şekilde elde edilen mülklerin vakfedilmesinden sevap hâsıl olamayacağı kanaatindedir. Bu şekilde temlik edilen köyler geri alınmalı ve bunların gelirleri, vakfedildikleri câmi vb. kuruluşların masrafına yetecek kısmın dışında, işe yarar timar sahiplerine tevzi edilmelidir.

Hayır kurumlarının faaliyetleri, bakım ve onarımları, suiistimal edilen yönlerine dair eleştiri ve önerileri burada ele almadık. Siyasetname, 1slahat risalesi vb. eserlerde bu konularda da gözlem ve eleştirilere yer verilmektedir. Meselâ Gelibolulu Mustafa Âli'nin Nushatü's- Selâtin adlı eserinin üçüncü bâbında ele alınan konulardan biri imaretlerdir. Burada, önceden mükemmel bir şekilde yemek tedarik edilen imaretlerdeki bozulma yüzünden ilim taliplerinin açlıkla karşılaştığı belirtilerek gerekli tedbirleri almayan vakıf yöneticilerinin ağır cezalara çarptırılması öneriliyor: "Fe-emmâ gâh ü bî-gâh yoklanub sorulsa (...) cürmi zuhur iden mütevelliyân-1 evkâfun nizâm-1 ahvâl-i enâm içün boyunları urulsa (...)'amâyirün ıslâhı ve müstehîkkînun sürûr ve inşirâhı mukarrer olub..." (Çerçi, 2015: 89b-92a (174-176) sadeleştirme; 389-392 transkripsiyon).

\section{Sonuç}

Sonuç olarak Osmanlı siyasetnâme-nasihatnâme literatüründe ekonominin ve maliyenin meselelerinin, adalet ve nizam ilkeleri çerçevesinde fiskalist bir anlayışla ele alındığını söylemek gerekir. Tavr-ı kadim ve geleneğe vurgu önemli bir başka boyuttur. Bununla birlikte uygulamada, eski usul ve tekniklerin yeni şartlara intibak ettirilmesi, biri geri plana itilirken diğerinin öne çıkarılması suretiyle 1slahat yapıldığını biliyoruz. Dolayısıyla katı bir gelenekçilikten ziyade esnek ve pragmatik bir gelenekçiliğin söz konusu olduğu belirtilmelidir. Bu çerçevede mirî arazinin ve emlâkin temlik edilmesi ve bilahare bunların bir kısmının vakfedilmesi olgusuna yönelik eleştirilerde bu bakış açısı dikkate alınmalıdır. Fiskalist bakışın yanında veya onun temel gerekçesi olarak da ordunun gücü meselesi öne çıkar. Daire-i adliye formülünde hazinenin güçlü olması ordunun güçlü olmasının sebebi olarak vurgulanmıştır. Dolayısıyla, Osmanlı Devletinin düşmanlarına ve bilhassa IV. Murad devrinin başlarında Safevîlere üstünlük sağlayabilmesi için tımarlı ordusunun da ulûfeli kapıkullarının da kritik bir önemi haiz olduğu açıktı. İşte bu gerekçelerle 1slahat risalesi yazan devlet adamları ve danışmanlar hazine gelirlerinin hak etmeyen kişilere temlik edilmesini sert bir şekilde eleştirmişler ve bu yolla tesis edilen vakıfların dinî/şer'î açıdan geçerliliğini sorgulamışlardır. Hiç şüphesiz burada sahih vakıflara yönelik bir eleştiri söz konusu değildir. Eleştirilerin özünde hazine gelirlerinin hak etmeyenlere tahsis edilmesi yatmaktadir. 


\section{Kaynaklar}

Aksüt, Ali Kemal (1939). Koçi Bey Risalesi. İstanbul.

Barkan, Ömer Lütfi (1942). “Osmanlı İmparatorluğu'nda Bir İskân ve Kolonizasyon Metodu Olarak Vakıflar ve Temlikler, I: İstila Devirlerinin Kolonizatör Türk Dervişleri ve Zaviyeler; II: Vakıfların Bir İskân ve Kolonizasyon Metodu Olarak Kullanılmasında Diğer Şekiller”. Vakıflar Dergisi. II, s. 279-386.

Barkan, Ömer Lütfi (1980). Türkiye’de Toprak Meselesi. İstanbul: Gözlem Yayınları. [Özgün makale: Barkan, Ö.L. 1942). "Türk İslâm Toprak Hukuku Tatbikatının Osmanlı İmparatorluğu'nda Aldığı Şekiller: İmparatorluk Devrinde Toprak Mülk ve Vakıflarının Hususiyeti”. İstanbul Hukuk Fakültesi Mecmuas1, 3, s. 906-942].

Çerçi, Faris (2015). Gelibolulu Mustafa Âlî, Siyaset Sanatı-Nushatü’s-Selatîn (İnceleme-Sadeleştirme-Metin-Tıpkıbasım). İstanbul: Büyüyen Ay Yayınları.

Genç, Mehmet (2000). Osmanlı Imparatorluğunda Devlet ve Ekonomi. İstanbul: Ötüken Neşriyat.

İlgürel, Sevim (1998). Hezarfen Hüseyin Efendi Telhîsü'l-Beyân fî̀ Kavânîn-i âl-i Osmân. Ankara: Türk Tarih Kurumu Yayınları.

İpşirli, Mehmet (1989). Selânikî Mustafa Efendi Tarih-i Selânikî. İstanbul, 2 cilt.

İpşirli, Mehmet (2007). Naîma Mustafa Efendi Târih-i Na'îmâ. Ankara: Türk Tarih Kurumu Yayınları.

İpşirli, Mehmet (2011). “Temlîk-nâme”. Türkiye Diyanet Vakfi İslam Ansiklopedisi, 40, s. 430-431.

Katip Çelebi (1979). Düstûrü'-amel li-1slahi'l-halel, Ayn Ali Efendi, Kavânîn-i Âl-i Osman der Hülasa-i Mezâmin-i Defter-i Divân, İstanbul 1280 (M. T. Gökbilgin'in önsözüyle tıpkıbasim). İstanbul.

Kınalıâde Ali (1248). Ahlâk-ı Alâî. III. Kahire: Bulak Matbaası.

Kurt, Yılmaz (1994 ). Göriceli Koçi Bey Koçi Bey Risalesi (Eski ve Yeni Harflerle). Ankara: EcdâdYayınları.

Kütükoğlu, Mübahat S. (1991). "Lütfi Paşa Asafnâmesi (Yeni Bir Metin Tesisi Denemesi)". Prof. Dr. Bekir Kütükoğlu’na Armağan. İstanbul. s. 49-99.

Murphey, Rhoads (1979). "The Veliyüddin Telhis: Notes on the Sources and Interrelations Between Koçi Beğ and Contemporary Advice to Kings". Belleten, 43 (171), s. 547-571.

Murphey, Rhoads (1985). Kanûnnâme-i Sultanî li Aziz Efendi, (Tıpkıbasım, Transkripsiyon ve İngilizce çeviri). Harvard University Pres.

Öz, Mehmet (2017). Kanun-ı Kadimin Peşinde-Osmanlı'da Çözülme ve Gelenekçi Yorumcularl. İstanbul: Dergâh Yayınları, 7. Bs.

Sariyannis, Marinos (2019). A History of Ottoman Political Thought up to the Early Nineteenth Century. Leiden-Boston: Brill.

Unan, Fahri (2004). İdeal Cemiyet İdeal Hükümdar İdeal Devlet- Kınal1-zâde Ali’nin Medîne-i Fâzıla sıl, Ankara: Lotus Yayınevi. 
Ülgener, Sabri F. (1981). İktisadi Çözülmenin Ahlak ve Zihniyet Dünyası. 2. Bs., İstanbul: Der Yayınları.

Yavuz, Kemal (1991). Şeyhoğlu Kenzü'l-Küberâ ve Mehekkü'l-Ulemâ (İnceleme-Metin-İndeks). Ankara: Türk Dil Kurumu Yayınları.

Yılmaz, Coşkun (2003). "Osmanlı Siyaset Düşüncesi Kaynakları İle İlgili Yeni Bir Kavramsallaştırma: Islahatnâmeler”. Türkiye Araştırmaları Literatür Dergisi, 1 (2), s. 299-338.

Yılmaz, Hüseyin (2003). Osmanlı Tarihçiliğinde Tanzimat Öncesi Siyaset Düşüncesine Yaklaşımlar. Türkiye Araştırmaları Literatür Dergisi, 1 (2), s. 231-298.

Yücel, Yaşar (1988). Osmanlı Devlet Teşkilatına Dair Kaynaklar (Kitab-ı Müstetab, Kitabu Mesâlihi'l-Müslimîn ve Menafi'i'l-Mü'minîn, Hırzü'l-Mülûk).Ankara: Türk Tarih Kurumu Yayınları. 